nor is sexual selection wrong. The awkward data for sexual-selection theory are not yet decisive. Also, as the mutual concessions and careful arguments between Clutton-Brock and Roughgarden show, there is often little empirical ground between them. Sexual selection starts with competition, but admits cooperation as a by-product. Social selection starts with mutual regard and cooperation, but admits competition when bargains break down. To compete, selfish genes must cooperate. To cooperate, genial genes must compete. It is difficult to sort between them. But Roughgarden succeeds in re-opening issues long thought closed.

Blaffer Hrdy's book is narrower in scope but also provocative. She argues that unlike other apes, Homo sapiens could never have evolved if human mothers had been required to raise their offspring on their own. Human infants are too helpless and too expensive in their demands for care and resources. So human females have to line up helpers - sometimes extending beyond their own kin - to raise their young. That requires both males and females to invest heavily in social skills for bargaining with other members of their groups. Blaffer Hrdy suggests that females in ancestral hunting and gathering groups may have thrived because they were free to be flexible in this way. Female flexibility was reduced when humans established settlements requiring male coalitions to defend them, probably leading to greater control of females by males.

More rides on these books than the relationship between the sexes. In her last chapter, Roughgarden distinguishes between Charles Darwin's repeatedly verified theory of "descent with modification", versus Herbert Spencer's unverified notion of the "survival of the fittest". It was Spencer who encouraged social Darwinism. Clearly we can go wrong if we attach faulty metaphors and narratives to evolutionary theory. The most refreshing aspect of both these books is the challenges they offer to what we thought we already knew.

John Odling-Smee is an emeritus fellow at Mansfield College, University of Oxford, Oxford OX13TF, UK.

e-mail: john.odling-smee@anthro.ox.ac.uk

\title{
Managing nature as Earth warms
}

Climate change is transforming the world as we know it. It disrupts biological clocks, pushes species to different latitudes and altitudes and shrinks biological diversity. It also challenges humanity to question its relationship with Earth; global warming is the antithesis of responsible stewardship. We look to science for guidance on how to turn back the hand of humankind, but it can provide only partial answers. Science is imperfect, unfeeling and slow compared with the steady rise of the global thermometer.

Into this mix of responsibilities, human identity and scientific uncertainty comes Anthony Barnosky's new book. Unlike other accounts of climate change, Heatstroke looks at the issue from the perspective of plants and animals. He introduces us to the Irish elk, the pack rat and biologists such as Jim Patton, a professor at the University of California, Berkeley - species and people that are helping to reveal the biotic signature of climate change.

Using many case studies, Barnosky explains how worldwide changes in climate are altering the reproductive rates, timing of breeding and living conditions of creatures. He is spot on in his description of new and exciting scientific findings, portraying them in an accessible and compelling way. Such findings include predictions of the existence of climates with no modern counterparts within 100 years, and a careful reconstruction of past climatic effects on small mammal communities. The reader becomes engulfed in a world of scientific discovery, searching through bones, walking transects to record the numbers of animal and plant species, and looking back across history to reveal the influence of climate on life.

This is not a happy book. Barnosky sounds the alarm about the biological effects of climate change, but his gloom and doom message could alienate readers. He repeatedly asserts that climate change will lead to permanent species loss: "At best, we seem to be witnessing wholesale changes in nearly every ecosystem on Earth. At worst, we may be witnessing the extinction of life as we've known it." The former statement is true, but the latter is extreme. In Yosemite and Yellowstone national parks in the United States, Barnosky reports changes in the composition and locations of species. But these places are not yet experiencing profound species loss. The public needs to understand how climate change is altering life on Earth and that such threats are very serious, but I worry that scientists risk a backlash if their primary message is the worstcase scenario.

Climate is a major determinant of where a species lives and how species interact. Biologists also know that climate change will outpace evolution for a great number of organisms, although perhaps not for bacteria, viruses and some insects. Barnosky describes the result as "like taking a color portrait and rendering it in black and white, or stripping all the harmonic notes out of a symphony". But not all organisms will be affected negatively; some will flourish. We need to figure out if climate change is eroding the species that humans value and replacing them with those that cause harm. And we must identify which species will be most affected, which ones will muddle through and which will rise to prominence. This information will help us to determine what sort of biotic world climate change is creating and what steps we might take to affect that change.

If we heed Barnosky's call to care about the impacts of climate change, we must reduce the greenhouse gases that we emit into the atmosphere and capture those already there. We could also help some species out.

Heatstroke describes the strategy of assisted migration - helping a species to relocate to a place where it might be expected to thrive.

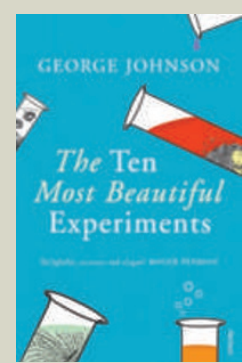

The Ten Most Beautiful Experiments

by George Johnson

(Vintage, $€ 8.99$ )

George Johnson's book covers ten of the most historically significant experiments in science including Isaac Newton's prisms and Ivan Pavlov's dogs. He does justice to each experiment, showing how ingenious and elegant it was - and how the process of experimenting may be as important as the conclusion.

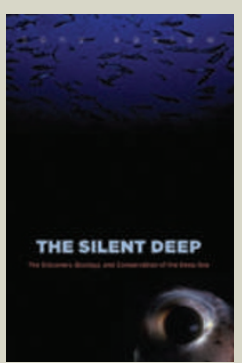

The Silent Deep: The Discovery, Ecology, and Conservation of the Deep Sea by Tony Koslow (Univ. Chicago Press, \$22.50)

Describing the huge variety of ocean life "with textbook depth on all aspects of deep-sea science and conservation," (Mark Schrope, Nature 447, 909-910; 2007), Tony Koslow examines how oceanography has developed and discusses human exploitation of the seas. 
This strategy aims to overcome dispersal barriers, so that species can survive climate change by altering their geographic distributions. Assisted migration is not a panacea, and it has serious risks, but it is an example of a new kind of thinking that we desperately need. We must devise other adaptation strategies to reduce the harmful effects of climate change where they occur.

Heatstroke concludes with ideas about how to slow the climate crisis, such as reducing energy consumption. But Barnosky stops short of offering suggestions that match the scale of the biodiversity crisis he has outlined. He could have suggested alternative strategies, and I hope that Heatstroke will inspire others to design potential solutions. We should also stop confusing assisted migration with 'Pleis-

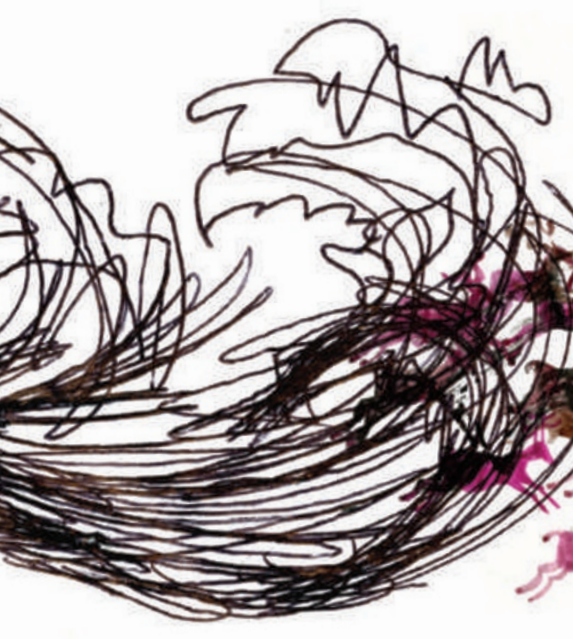

tocene rewilding, an idea that Barnosky raises after assisted migration. Rewilding would return ecosystems to their state before historical climatic change by transporting large animals and predators across continents. But rewilding has different goals and potentially greater consequences than assisted migration, and it has muddied the waters for productive debates about such strategies.

After reading Heatstroke, I felt the urge to go outside and experience nature at first hand, to develop a deeper appreciation for

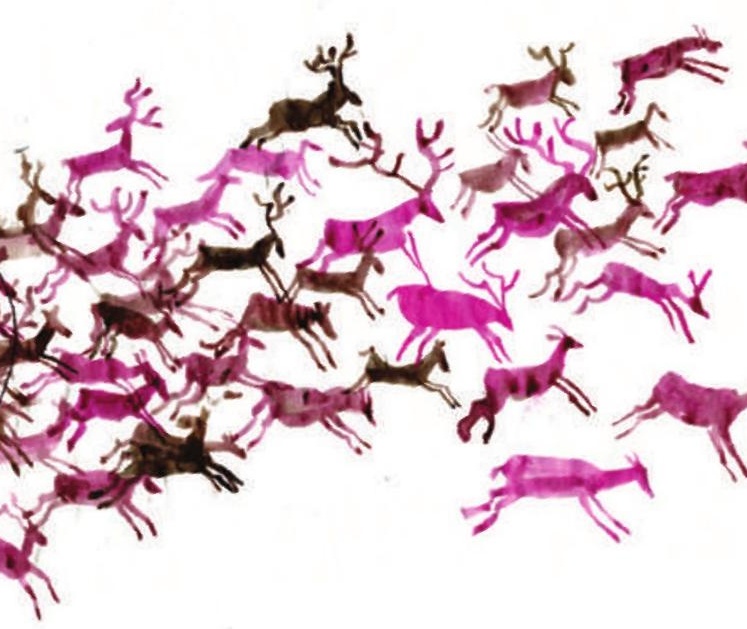

the life that climate change threatens. If the public at large could be similarly inspired, there might be hope for positive change. Read this book, and reflect on your own views about humanity's place in nature. Then plant a tree, walk to work, and go and call your political representative.

Jessica J. Hellmann is professor of biological sciences at the University of Notre Dame,

107 Galvin Life Science Center, Notre Dame, Indiana 46556, USA.

e-mail: hellmann.3@nd.edu

\section{Tales of top models}

\author{
Pavlov's Dogs and Schrödinger's Cat: \\ Scenes From the Living Laboratory \\ by Rom Harré \\ Oxford University Press: 2009. 288 pp. \\ $£ 16.99, \$ 34.95$
}

This charming book is entertaining, thoughtprovoking and frustrating. It is worth reading for all three of those reactions.

Written by the distinguished philosopher Rom Harré, Pavlov's Dogs and Schrödinger's Cat is based on the premise that just as scientists interrogate the real world with inanimate equipment such as flasks, telescopes and DNA sequencers, we also do so with animate organisms or their parts. Thus, dogs were the apparatus Ivan Pavlov used to study conditioned responses, Galapagos finches the devices used by Peter and Rosemary Grant to study natural selection, and peas and flies the tools used by
Gregor Mendel and Theodosius Dobzhansky, respectively, to elucidate genetics. The use of organic equipment extends beyond the biological sciences: for a time, frogs' legs and canaries were more sensitive detectors of electricity and carbon monoxide than any machine, and we still explore Earth's climatic history using longdeparted organisms. Harré romps through five centuries of vignettes, asking who used these organic tools, why and to what end.

And it is an entertaining romp, partly because it is so well written, and partly because the animals and plants involved generate great stories. Some stories are lovely, such as William Buckland's conclusion from cave bones that the UK county of Yorkshire was tropical before Noah's flood. Some are sad, such as the experiments on filial love and maternal separation in monkeys by Harry Harlow, studies that caused great distress to the animals involved, and that have not stood the test of time. And some are horror stories - including one of the most gripping and succinct summaries of the Lysenko fiasco in Soviet genetics I have read. The scientific questions that lie behind Harrés stories are often startling; for instance, what are the psychological underpinnings of those who commit genocide? The experimental ingenuity of scientists is sometimes breathtaking, such as Stephen Hales' determination of blood pressure using wax, brass pipes, glass tubes and expiring horses. Despite the brevity of each case study, the scientists emerge as real people, with varying degrees of brilliance and interpersonal skills. As a lucid illustration of the messy, chaotic and glorious professional world we scientists have always inhabited, this book is great.

Yet the book is more thought-provoking than a simple storytelling exercise. It is organized not as a history, nor by scientific subject, but by the principles of the philosophy of science. Chapters are devoted to organisms as detecting and measuring devices, and as tools for exploration, for testing hypotheses and for modelling reality. This organization generates

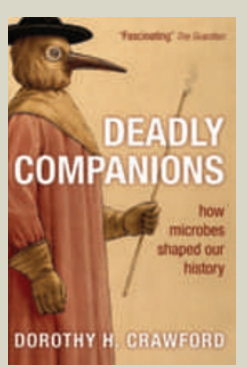

Deadly Companions: How Microbes

\section{Shaped Our History}

by Dorothy H. Crawford

(Oxford Univ. Press, E8.99)

From the origin of the first microorganisms on Earth, Dorothy Crawford describes how microbes have evolved alongside humanity. Showing how they have altered human history, such as through plague or famine, she explains how humanity has affected microbes in return - and why this will never change.

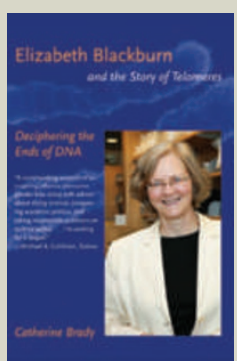

Elizabeth Blackburn and the Story of Telomeres: Deciphering the Ends of DNA by Catherine Brady

(MIT Press, \$15.95)

This compelling tale describes the science and politics behind molecular biologist Elizabeth Blackburn's great discoveries. She "emerges as a valuable role model in the sometimes unsettling treatment of women in the world of science", wrote Maria A. Blasco (Nature 450, 613-614; 2007). 